\title{
BIOLOGY OF TRIATOMINAE (REDUVIIDADE, HEMIPTERA) \\ FROM NORTH OF FORMOSA COUNTY (GOIASS - BRAZIL). III. LENGTH OF LIFE CYCLE OF PSAMMOLESTES TERTIUS LENT AND JURBERG 1965.
}

\author{
Dalva A. Mello*
}

In the present work the life cycle of Psammolestes tertius was studied. The mean kength, in days, from, each stage was: 26.3 ( \pm 1.7 ) (1st), 28.6 ( \pm 1.8 ) (2nd), $28.4 .( \pm 1.8)(3 r d), 32.2( \pm 1.9)(4 t h)$ and 33.5 ( \pm 5.8$)(5$ th $)$.

The mean egg incubation period was 15.7 days $( \pm 1.7)$. Overall mortality was 48.9\% and egg viability was $65.7 \%$.

\section{INTRODUCTION}

Psammolestes tertius described by Lent and Jurberg (1965) is a reduviidae found in the states of Săo Paulo, Minas Gerais, Goiás, Paraná, Ceará and Pernambuco.

Observations on eçological aspects of $P$. tertius were made by Barretto ot al. " in some regions of the states of São Paulo and Minas Gerais. Sherlock et al. ${ }^{6}$ also studied this reduviidae species in Bahia State.

The role of $P$. tertius in the epidemiology of Chagas disease is not clear yet. Dias ${ }^{3}$ believes that $P$. tertius may contribute to the transmission of $T$. cruzi in wild foci. As demonstrated by Barretto et al. ${ }^{1}$ and Dias ${ }^{3}$ the biotope of $P$. tertius may be visited by some mammal species which are well known to be reservoirs of $T$. cruzi.

Barretto e Albuquerque ${ }^{2}$ found a biotope of $P$. tertius visited by Didelphis azarae and Rattus rattus: $14,2 \%$ of 106 triatominae collected and examined for $T$. cruzi were positive for this flagellate.

Very little is known about the life cycle of P. tertius. There is only one paper in the literature dealing with some aspects of the life cycle of this triatominae (Dias, 1968).

The main objective of this paper is to present quantitative data on the life cycle of $P$. tertius.

\section{MATERIAL AND METHODS}

\section{Origin of the population studied}

The population of $P$. tertius studied in this paper was originated from eggs of females caught in Phacellodomus rufrifons nests, in wild environment.

The insects came from a place about 156 $\mathrm{Km}$ northeast of Brasilia, D.F., (Brazil) on the BR-020 highway.

The egg incubation period was observed on 105 specimens.

The total number of individuals studied from first instar nymph to adult was 37.

\section{Maintenance of the population}

The population studied was maintained and observed as described by Mello ${ }^{5}$.

The insects were kept in an incubator without light.

The temperature and relative humidity were controlled by a thermohidrograph (Lambrecht, KG). The mean temperature was $23.2^{\circ} \mathrm{C}$ and the relative humidity was $87 \%$.

The statistical analysis was effected as described by Mello ${ }^{5}$.

\footnotetext{
* Faculty of Health Sciences. University of Brasilia. This work was partially supported by a grant from the National Research Council of Brazll (SIP/08-032 - CNPq-6228/75) and the Ministry of Health.
}

Submitted to publication on April/18/1977 
Vol. XI - No 4

\section{RESULTS}

The complete cycle length, from $e g g$ to adult, had an average of 164.7 days.

The egg incubation period is shown in table 1. The mean was $15.7( \pm 1.7)$ with $65.7 \%$ of viable eggs.

The occurrence of ecdyses, for all developmental stages, is shown in table 2 . Overall mortality was $\mathbf{4 8 . 9 \%}$. The female/ male ratio was 1.3 .

TABLE 1

Incubation period of ecgs of P. tertius under laboratory conditions

\begin{tabular}{cc}
\hline Incubation days & No of viable egos \\
\hline 14 & 17 \\
15 & 18 \\
16 & 9 \\
18 & 25 \\
\hline Total & $105(65.7 \%)$ \\
\hline
\end{tabular}

TABLE 2

Duration in days of different developmental stages of $P$. tertius

\begin{tabular}{|c|c|c|c|c|c|}
\hline $\begin{array}{l}\text { Developmental } \\
\text { tages } \\
\text { Ecdyees } \\
\text { (closs int. in } \\
\text { deys) }\end{array}$ & NI & NII & NIII & NIV & NV \\
\hline $\begin{array}{r}10-14 \\
15-19 \\
20-24 \\
25-29 \\
30-34 \\
35-39 \\
40-44 \\
45-49 \\
50-54 \\
+60\end{array}$ & $\begin{array}{r}0 \\
3 \\
2 \\
10 \\
6 \\
2 \\
2 \\
0 \\
5 \\
7\end{array}$ & $\begin{array}{r}1 \\
0 \\
2 \\
16 \\
9 \\
1 \\
2 \\
1 \\
0 \\
1\end{array}$ & $\begin{array}{r}0 \\
0 \\
6 \\
15 \\
5 \\
4 \\
0 \\
1 \\
0 \\
0\end{array}$ & $\begin{array}{r}0 \\
0 \\
1 \\
2 \\
11 \\
5 \\
1 \\
1 \\
2 \\
2\end{array}$ & $\begin{array}{r}0 \\
0 \\
0 \\
1 \\
4 \\
11 \\
5 \\
0 \\
0 \\
2\end{array}$ \\
\hline $\begin{array}{l}\text { Subtotal } \\
\text { Dead } \\
\text { Total }\end{array}$ & $\begin{array}{l}37 \\
10 \\
47\end{array}$ & $\begin{array}{r}33 \\
4 \\
37\end{array}$ & $\begin{array}{r}31 \\
2 \\
33\end{array}$ & $\begin{array}{r}25 \\
6 \\
31\end{array}$ & $\begin{array}{r}23 \\
2 \\
25\end{array}$ \\
\hline
\end{tabular}

TABLE 3

Mortality and mean duration of different developmental stagos of $P$. tertius

\begin{tabular}{cccc}
\hline $\begin{array}{c}\text { Develop. } \\
\text { stages }\end{array}$ & $\begin{array}{c}\text { Mean duration } \\
\text { (davs) }\end{array}$ & $\begin{array}{c}\text { Mortality } \\
(\%)\end{array}$ & $\begin{array}{c}\text { Survival } \\
(\%)\end{array}$ \\
\hline eggs & $15.7( \pm 1.7)$ & - & - \\
I & $26.3( \pm 1.7)$ & 21.2 & 78.7 \\
II & $28.6( \pm 1.8)$ & 10.8 & 89.1 \\
III & $28.4( \pm 1.8)$ & 6.1 & 93.9 \\
IV & $32.2( \pm 1.9)$ & 19.3 & 80.6 \\
$V$ & $33.5( \pm 5.8)$ & 8.0 & 92.0 \\
\hline
\end{tabular}

\section{COMMENTS}

Dias ${ }^{3}$ studying the biology of $P$. tertius under laboratory conditions, observed that the entire life cycle (egg-adult) of this triatomine lasted from 95 to 128 days. The egg incubation period lasted 20 days and first instar nymphs varied from 7 to 12 days.

In comparison with the data presented by Dias $^{3}$, the life cycle of $P$. tertius studied in the present paper was much longer (164.7 days).

Although Dias ${ }^{3}$ does not present numerical data on, the mortality of $P$. tertius he comments on the high mortality of the population studied by him. In this paper, total mortality (1st instar nymph to adult) of $P$. tertius was high $(48.9 \%)$ and 69 viability was low (65.7\%).

P. tertius is not an easy species to breed in the laboratory. High humidity (87\%) seems to be an important condition for the maintenance of the species in the laboratory.

\section{ACKNOWLEDGEMENTS}

The autor thanks Eudmar C. Lopes for his assistance in laboratory work. 


\section{RESUMO}

No presente trabalho foi estudado o ciclo biológico de Psammolestes tertius. A duraça do ciclo de ovo a adulto foi em torno de 164.7 dias. A média de duração em dias para cada estágio foi: 26,3 ( $\pm 1,7)$ para o primeiro, $28,6( \pm 1,8)$ para o segundo, $28,4( \pm 1,8)$ para o terceiro, $32,3( \pm 1,9)$ para o quarto e $33,5( \pm 5,8)$ para 0 quinto.

A média do periodo de incubação dos ovos foi 15,7 ( $\pm 1,7)$.

A mortalidade geral foi de $48,9 \%$ e a viabilidade dos ovos foi de $65,7 \%$.

\section{REFERENCES}

1. BARRETO M. P. \& CARVALHEIRO J.

$R$. Estudos sobre reservatórios silvestres de Trypanosoma cruzi. XVIII. Observa. ções sobre a ecologia do Psammolestes tertius Lent \& Juberg, 1965. Rev. Bras. Bio. 27: 13-25, 1967.

2. BARRETO M. P. \& ALBUQUERQUE R. $D$. Estudos sobte reservatórios e vetores silvestres do Trypanosoma cruzi. XXXIII. Infecção experimental e natural do Psammolestes tertius Lent \& Juberg, 1965, pelo T. cruzi. Rev. Inst. Med. Trop. 11: 165-168, 1969.

3. DIAS J. C. Notas sobre a biologia do Psammolestes tertius Lent \& Juberg, 1965, no oeste do estado de Minas Gerais. Rev. Bras. Mal. D. Trop. 20: 171-187, 1968.
4. LENT H. \& JURBERG J. O gênero Psammolestes Bergroth, 1911, com um estudo sobre a genitalia da espécie (Hemiptera, Reduviidae, Triatominae). Rev. Bras. Biol. 25: 349-376, 1965.

5. MELLO, D. A. Biology of Triatominae (Reduviidae -. Hemiptera) from North of Formosa Conty (Goiás Brazill). I. Length of life cycle of $T$. sordida (Stal, 1859). Rev. Soc. Bras Med. Trop. X: 327, 1976.

6. SHERLOCK, I.A. \& SERAFIM, E. M. Fauna Triatominae do Estado da Bahia, Brasil. VI. Prevalência geográfica da infecção dos triatomíneos por $T$. cruzi. Rev. Soc. Bras. Med. Trop. 8: 129-142, 1974. 